Arab World English Journal (AWEJ) Volume 12. Number3 September 2021

DOI: https://dx.doi.org/10.24093/awej/vol12no3.4

Pp. $51-65$

\title{
Palestinian EFL University Students' Problems with the Reading Sections of the TOEFL Internet-based Test and the Revised TOEFL paper-delivered Test
}

\author{
Enas Abdullah Hammad \\ Al-Aqsa University, Gaza, Palestine \\ Email: enas.hammad@hotmail.com
}

Received: 5/23/2021

Accepted: 8/16/2021

Published: 9/24/2021

\begin{abstract}
Despite Palestinian university students' problems with the Test of English as a Foreign Language Internet-based Test, no researchers approached this research area in the Palestinian English as a Foreign Language context. The present study attempted to answer a question focusing on Palestinian university students' problems with the reading sections of the Test of English as a Foreign Language Internet-based Test and the revised Test of English as a Foreign Language paper-delivered test. The participants were 65 fourth-year students studying English at Al-Aqsa University. The researcher employed four instruments: a test, a group semi-structured interview, and two individual semi-structured interviews. Results showed the students' problems with the reading sections of the two types of tests, such as the irrelevance of the topics of the tests to the students' content background knowledge, students' lack of exposure to lengthy passages, students' slow reading speed, and the students' lack of linguistic proficiency. Additionally, the study offered many recommendations for Educational Testing Service experts and Al-Aqsa university students and instructors.
\end{abstract}

Key Words: Internet-based Test, Palestinian EFL university students, reading

Cite as: Hammad, E. A. (2021). Palestinian EFL University Students' Problems with the Reading Sections of the TOEFL Internet-based Test and the Revised TOEFL paper-delivered Test . Arab World English Journal, 12 (3) 51-65. DOI: https://dx.doi.org/10.24093/awej/vol12no3.4 


\section{Introduction}

The Test of English as a Foreign Language (TOEFL) Internet-based Test (iBT) is one of the essential standardized tests used worldwide. According to ETS (2009), more than 4,500 test centers in 180 countries administer the TOEFL iBT test. Researchers and practitioners have recently conducted several studies on the use of the TOEFL iBT test in English as a Foreign Language/ English as a Second Language (EFL/ESL) settings. For instance, some studies (e.g., Akmal, Risdaneva, Habiburrahim, \& Sari, 2020; Asrida \& Fitrawati, 2016; Fajri, 2019) focused on EFL/ESL students' problems with the TOEFL iBT test. Other relevant studies (e.g., Assiri, 2011) centered on the test-taking strategies used by EFL/ ESL learners when responding to the reading tasks of the TOEFL iBT test. Additionally, Cho and Bridgeman (2012) and Vu and Vu (2013) investigated the relationship between EFL/ESL university students' scores on the TOEFL iBT test and their Grade Point Average (GPA) scores.

To the best of the researcher's knowledge, no researchers approached this research area in the Palestinian EFL context. The researcher of this study has worked as an academic instructor of English Language Teaching (ELT) courses for 14 years at Al-Aqsa University, and she could notice that most English department students had problems with the reading sections of the TOEFL iBT test and the revised TOEFL paper-delivered test. Thus, the current study aimed to investigate Al-Aqsa University EFL students' issues with the two types of tests through answering the following questions:

1. What is Al-Aqsa University EFL students' performance level in the revised TOEFL paper-delivered reading test?

2. How do Al-Aqsa university students who did not attend any TOEFL preparation courses perceive their problems with the revised TOEFL paper-delivered reading test?

3. How do Al-Aqsa university EFL students with background experiences in TOEFL iBT preparation courses (2019-2021) perceive their problems with the TOEFL iBT reading test?

4. What are Al-Aqsa University EFL students' problems with the reading section of the TOEFL iBT test as perceived by their instructors?

\section{Literature Review}

The literature review consists of a theoretical framework and previous studies related to the TOEFL iBT test.

\section{Theoretical Framework}

The theoretical framework introduces the definition of the TOEFL test, the reading section of the TOEFL iBT test, the strategies included in the TOEFL iBT reading test, and the topics used in the TOEFL iBT reading test.

Definition of 'the TOEFL test'

According to ETS (2019, p. 3), 'the TOEFL test' is "a standardized test designed to measure the ability to understand and to use English as it is used in a North American academic setting such as a university." ETS (2009) provides that more than 4,500 test centers in 180 countries administer the TOEFL test. 
The TOEFL test has evolved through three phases: a paper-based test, a computer basedtest, and an internet test (Assiri, 2011). Before 1998, the TOEFL test test measured one isolated aspect of language knowledge. The experts launched the TOEFL computer-based test in 1998. Then, they established the TOEFL iBT test in 2005, which is a direct measure of the test takers' communicative abilities in all four basic skills, including reading, listening, speaking, and writing (ETS, 2019).

\section{The Reading Section of the TOEFL iBT Test.}

The reading section is the first section on the TOEFL iBT test, and it aims to evaluate the test takers' abilities to understand university-level academic texts (ETS, 2009). According to ETS (2019, p. 7), the reading section "measures the ability to read, understand, and analyze short passages similar in topic and style to those that North American college and university students encounter in their courses." Additionally, ETS (2008) provides that the reading section may include three to five reading passages, each with a 600-700 word text and 12 to 14 question items. The time allocated for completing this section is between 60 and 100 minutes, at a rate of 20 minutes per reading passage. The passages cover different subjects, and all selections covered three basic categories: exposition, argumentation, and history.

In August 2019, the TOEFL test underwent many changes in the test sections, including the reading section. The number of the reading section passages is either three or four. The time devoted to the reading section is either 54(three passages) or 72 (four passages) minutes. The experts slightly shortened each passage, and established ten questions with each selection i.e., vocabulary questions, reference questions, factual questions, negative factual questions, sentence simplification questions, inference questions, rhetorical purpose questions, inserting text questions, prose summary questions, and fill in table questions (Putlack, Poirier, \& Jacobs, 2020).

\section{The Strategies Included in the TOEFL iBT Reading Test}

According to Putlack, Poirier, and Jacobs (2015), the TOEFL iBT reading test is concerned with many reading strategies, such as guessing meanings of specific words, distinguishing relationships between words and their referents, identifying facts or data explicitly covered in the passage, determining main points and ideas, inferring facts or information, considering the relationship between the information mentioned and the purpose of such information, considering various aspects i.e., logic, grammar, connecting words for determining wherein a set another sentence should be placed, and considering cause and effect relationship.

\section{The Topics Used in the TOEFL Reading Test}

As for the topics used for testing, the test designers focused on science topics, i.e., biology, zoology, astronomy (Putlack et al., 2020). Moreover, Stirling (2021) points out that the issues of the TOEFL iBT reading comprehension passages are related to first and second-year university life science and humanities courses i.e., biology, economics, art, geology, zoology, literature, and history.

In case of existing technical problems, test centers usually use the revised TOEFL paperdelivered test. The revised TOEFL paper-delivered test consists of listening, reading, and writing 
Arab World English Journal (AWEJ) Volume 12. Number 3. September 2021

Palestinian EFL University Students' Problems with the Reading

Hammad

sections. The test is about 2.5 hours long, and students have to take all areas on the same day (ETS, 2019).

\section{Previous Studies}

Many studies have focused on EFL/ESL students' problems with the TOEFL iBT test. For instance, Akmal et al. (2020) aimed at discovering the challenges encountered by six English language teachers in teaching the TOEFL preparation courses to students in Indonesian high schools. The study gathered its data through in-depth interviews. The results showed the problems the students encountered with the TOEFL preparation courses, including students' language proficiency, their passive attitudes, class size, and lack of time. Moreover, Asrida and Fitrawati (2016) investigated 26 Nigerian EFL students' problems with the TOEFL reading test. The instrument used in this study was the TOEFL reading test. The study explored the participants' difficulties in identifying main ideas, stated details, and using context to determine the meaning of unfamiliar words. Fajri (2019) also identified the challenges encountered by 20 Indonesian EFL university students in completing the TOEFL reading comprehension test. The study utilized many instruments, including an observation card, an interview, a questionnaire, and a quiz. Results showed that inference questions were the most difficult (33\%), followed by vocabulary questions (40\%) and questions requiring unstated answers (50\%). Likewise, Girsang, Marbun, Turnip, and Saragih (2019) examined the difficulties encountered by Indonesian EFL high school students in answering the questions of the TOEFL reading comprehension test. The instruments used in the study were interviews and questionnaires. The results found that the most significant problems were the participants' lack of interest in reading, students' lack of vocabulary, lack of practice, and lack of time. Furthermore, Samad, Jannah, and Fitriani (2017) centered on 30 Syiah Kuala University students' experiences with the TOEFL reading comprehension test. The data of the TOEFL test and a questionnaire indicated that the most challenging skills were deducing implied details, using context for guessing meanings of difficult words, finding main ideas, and determining meanings from word parts.

Other relevant studies centered on the test-taking strategies used by EFL/ESL learners when responding to the reading assignments. For instance, Assiri (2011) was concerned with the test-taking techniques used by 25 Arab ESL learners when responding to the reading tasks and items of the TOEFL iBT test. The participants were attending undergraduate and graduate programs in the United States at a south-western university. The study utilized stimulated recalls, self-observations, and retrospective interviews. Findings concluded that the participants employed a variety of strategies, such as test-management strategies. Additionally, Zalha, Alfiatunnur, and Kamil (2020) identified the strategy of six English Language Education Department students of UIN Ar-Raniry Banda Aceh in dealing with the reading comprehension section of the TOEFL test. Data of semi-structured interviews revealed five strategies the participants employed when dealing with the reading comprehension section of the TOEFL test i.e., skimming, scanning, using context to understand the meaning of unfamiliar vocabulary, and utilizing background knowledge.

Furthermore, Cho and Bridgeman (2012), O’Dwyer, Kantarcioglu, and Thomas (2018), and $\mathrm{Vu}$ and $\mathrm{Vu}$ (2013) studied the relationship between ESL/EFL university students' scores on the TOEFL iBT test and their academic performance. Cho and Bridgeman (2012) focused on the relationship between scores of 2594 undergraduate and graduate students from 10 universities in the United States on the TOEFL iBT test and their academic performance. The data consisted of 
students' GPA scores, detailed course information, and admissions-related test scores. Results indicated that the predictive validity expressed in terms of correlation did not appear to be strong. Nevertheless, the general pattern shown in the expectancy graphs indicated that students with higher scores tended to earn higher GPAs. Likewise, O’Dwyer, Kantarcioglu, and Thomas (2018) focused on the relationship between the TOEFL iBT scores and academic performance levels of 286 Turkish undergraduate students. Correlations between the test scores and the English-language course GPAs confirmed a moderate to moderately high predictive validity for English-language course GPAs. In addition, $\mathrm{Vu}$ and $\mathrm{Vu}$ (2013) investigated the correlation between the TOEFL test scores of 464 international graduate students at a Midwestern public university in the U.S. and their GPA scores. The study collected the data through a survey, and results showed that the TOEFL test score was not an accurate and effective predictor of academic performance as measured by GPA.

The study of Galikyan, Madyarov, and Gasparyan (2019) explored the perceptions of 202 student test takers and nine teachers of the TOEFL Junior Standard test in an afterschool program in Armenia. The study employed questionnaires, and the findings revealed the correspondence between the test construct and test users' perceptions. Sari (2019) also identified English language teachers' perceptions of the TOEFL preparation program in senior high school. The study collected its data through in-depth interviews. The participants were six English language teachers giving the TOEFL preparation courses in old high schools in Banda Aceh and Aceh Besar. The results showed that all teachers had positive attitudes toward the TOEFL program. They believed that the TOEFL test should be introduced in the first grade to prepare students' future studies and careers. In addition, Soureshjani, Riahipour, and Safikhani investigated the attitudes of Iranian EFL students towards the TOEFL iBT test. The questionnaire used in the study revealed that most participants had positive attitudes toward the TOEFL iBT test.

None of the previous studies probed Palestinian EFL university students' problems with the reading sections of the TOEFL iBT test and the revised TOEFL paper-delivered test.

\section{Methods \\ Research Design}

The researcher utilized the descriptive method to explore Al-Aqsa university students' problems with the reading section of the TOEFL iBT test. Ariola (2006) provides that the descriptive method is the most popular employed in researches because such method can introduce a description of current events, phenomena, states, or affairs.

\section{Participants}

The researcher used the stratified random sample technique to select the study participants. They were 65 (45 females and 20 males) fourth-year students joining the department of English at Al-Aqsa University in the academic year 2020-2021. The researcher decided on the fourth-year students since the participants passed most English language courses, explicitly reading one and reading two. All students studied English as a foreign language for fifteen years, and they were between twenty and twenty-two years old. 
Then, the researcher conducted semi-structured interviews with fifteen students selected from the 65 ones to gather detailed data about the students' problems with the revised TOEFL paper-delivered reading test. The fifteen participants included male and female students with different proficiency levels in the English language i.e., students whose achievement levels ranged from $85 \%-100 \%, 75 \%-85 \%$, below- $75 \%$.

Additionally, the researcher interviewed four other English majors who had background experiences with the TOEFL iBT reading test and attended TOEFL preparation courses (20192021).

Finally, the researcher interviewed three instructors teaching English reading to English department students at Al-Aqsa University. The first was a 31-year experience male instructor. The second was a 14-year experience female instructor. The third was a five years' experience male instructor.

\section{Research Instruments}

First Semi-structured Interview (an individual interview)

To determine the students' problems with the revised TOEFL paper-delivered reading test from the students' perspectives, the researcher designed a semi-structured interview. According to Menter et al. (2011), interviews help understand people's attitudes and rationale and gain great insights. After reviewing relevant references (e.g., Akmal et al., 2020; ETS, 2019; Putlack, et al., 2020), the researcher developed the interview questions (Appendix A). Each interview lasted thirty minutes and was recorded for transcription.

\section{Second Semi-structured Interview (an individual interview)}

To gather detailed data about the problems of the TOEFL reading iBT test as perceived by the students with background experiences in the TOEFL iBT reading preparation courses (2019-2021), the researcher designed a semi-structured interview. The researcher used relevant references (e.g., Akmal, et al., 2020; ETS, 2019; Putlack et al., 2020) to write the interview questions (Appendix B).

\section{Third Semi-structured Interview (an individual interview)}

Finally, the researcher designed an interview to collect in-depth data about Al-Aqsa University students' problems with the TOEFL iBT reading test from the perspectives of EFL reading instructors at Al-Aqsa University (Appendix C).

\section{The Revised TOEFL paper-delivered Test (ETS, 2021)}

The study employed the revised TOEFL paper-delivered Test (ETS, 2021) to assess the students' performance in reading comprehension (Appendix D). It measures the student's ability to understand academic passages written in English. It includes three sets associated with several questions. The questions focus on the main ideas and essential details in the extracts. Students have to answer the test questions within 54 minutes. Most questions require only one answer. Questions requiring more than one answer have particular directions.

\section{Research Procedures}

The study administered its instruments in the second semester of 2020-2021 (February 2021). First, the researcher administered the revised TOEFL paper-delivered reading test to 65 
fourth-year students selected randomly from all fourth-year English majors at Al-Aqsa University. Second, she conducted semi-structured interviews with fifteen chosen students from the 65 students. The fifteen students took the revised TOEFL paper-delivered reading test for the first time and did not attend any TOEFL preparation courses. The researcher interviewed them in five groups, each of three students with different proficiency levels. Third, the researcher interviewed four other students with background experiences with the TOEFL iBT reading test and attended TOEFL preparation courses. The researcher interviewed each student separately. Fourth, the researcher conducted separate interviews with three English reading instructors. Each of the interviews lasted for twenty-thirty minutes and was audio-taped. Furthermore, the participants used their native language (Arabic) while talking to express their thoughts and views freely.

To analyze the qualitative data, the researcher employed the qualitative data analysis steps given by Lodico, Spaulding, and Voegtle (2006) in analyzing the interviews. The interviews with all participants in the present study were transcribed, coded, and organized into many categories including four categories related to the fifteen students' discussions (i.e., the irrelevance of the topics of the revised TOEFL paper-delivered reading test to students' content background knowledge, irrelevance of the vocabulary included in the revised TOEFL paper-delivered reading test to students' background knowledge, lack of opportunities for training students on practicing higher-order thinking skills, and students' inability to work under time pressure), two categories related to the four students' interviews (i.e., the irrelevance of the topics of the TOEFL iBT reading test to students' content background knowledge, irrelevance of the vocabulary included in the TOEFL iBT reading test to students' background knowledge), and four categories related to the three instructors' interviews (i.e., the irrelevance of the topics of the TOEFL iBT reading sets to students' content background knowledge, students' lack of linguistic proficiency, students' lack of exposure to lengthy passages, and students' slow reading speed). Another researcher reviewed and coded the data to establish credibility, and the two researchers agreed on $85 \%$ of the coded data.

\section{Results}

\section{Results of the Revised TOEFL paper-delivered Reading Test}

First, the revised TOEFL paper-delivered reading test was employed to determine the participants' performance levels in the revised TOEFL paper-delivered reading test. Table 1 shows the descriptive statistics for the participants' performance levels in the revised TOEFL paper-delivered reading test.

Table 1. Descriptive statistics for the participant's performance in the revised TOEFL paperdelivered reading test

\begin{tabular}{|l|l|l|}
\hline Level & Raw Frequency & Percent Frequency \\
\hline $90 \%$ and above & 0 & 0 \\
\hline $80 \%-89.9 \%$ & 0 & 0 \\
\hline $70 \%-79.9 \%$ & 15 & $23 \%$ \\
\hline Less than $70 \%$ & 50 & $77 \%$ \\
\hline Total & 65 & $100 \%$ \\
\hline
\end{tabular}


The Table shows that $77 \%$ of the students' scores were less than $70 \%$, which indicates that the students' performance level in the revised TOEFL paper-delivered reading test was flawed.

\section{Results of the First Semi-structured Interview (a focus group interview)}

For identifying the participants' problems with the revised TOEFL paper-delivered reading test, the researcher conducted semi-structured interviews with fifteen students who administered the revised TOEFL paper-delivered reading test without taking any TOEFL preparation courses. The interviews data showed that most of the students (fourteen students) complained that the test topics are complicated and unfamiliar.

Participant T. 15 (a male student with a low proficiency level): I think that the topics of the sets are very tough, unfamiliar, and uninteresting.

Participant T. 2 (a female student with a high proficiency level): The topics are very challenging, and they are unrelated to our specialization.

As the topics of the revised TOEFL paper-delivered reading collections, the vocabulary included in such sets was strange and difficult to understand.

Participant T. 1 (a female student with a high proficiency level): The reading sets include difficult and strange words. Such words are not related to the subjects I study in the university. We learn ELT and literature courses. How then can we recognize the meanings of such difficult words? We never studied courses related to such topics.

Participant T. 5 (a female student with an intermediate proficiency level): I felt anxious when I met difficult words while reading. I could guess only $30 \%$ of the unknown words.

A third problem is the lack of opportunities for training students on practicing higher-order thinking skills (i.e., predicting, summarizing, and finding information implied in the passages). More than half of the students (ten students) reported that they used to answer questions requiring explicit answers.

Participant T. 9 (a male student with a high proficiency level): The questions are very tough, as they require implicit information.

Participant T. 4 (a female student with an intermediate proficiency level): Some questions were difficult, such as the summarizing questions. Answering such questions requires understanding the whole passage.

Participant T. 6 (a male student with an intermediate proficiency level): I never worked on such questions in reading classes.

It was evident that most of the participants did not use to practice higher-order thinking skills in reading classes (i.e., predicting, drawing inferences, and summarizing). Consequently, they encountered difficulties when answering the questions of the revised TOEFL paper-delivered reading test.

A fourth problem is the students' inability to work under time pressure. Many interviewees complained that they felt stressed because the time allocated for the revised TOEFL paper-delivered reading test was inadequate. 
Participant T. 11(a male student with an intermediate proficiency level): The time was not enough for understanding the passages and answering all questions associated with them. Unlike this test, my reading tests in school and university were not stressful.

Participant T. 14 (a female student with a high proficiency level): I had to look at my watch many times during the test. That is why I felt anxious, and I did not like the test at all.

It seems that most students interviewed were not used to practicing reading tests under time pressure, and therefore they felt anxious when taking the revised TOEFL paper-delivered reading test.

In short, the interviews data reported the students' problems with the revised TOEFL paperdelivered reading test. The study showed the irrelevance of the topics of the TOEFL paperdelivered reading sets to the students' content background knowledge, the irrelevance of the vocabulary included in the TOEFL paper-delivered reading scenes to the students' background knowledge, lack of opportunities for training students on practicing higher-order thinking skills (i.e., predicting, summarizing, and finding information implied in the passages), and students' inability to work under time pressure.

\section{Results of the Second Semi-structured Interview (an individual interview)}

The researcher conducted semi-structured interviews with four students who had background experiences in the TOEFL iBT reading test. The interviews data revealed that congruent with participants' views on the revised TOEFL paper-delivered reading test; the participants complained that the topics of the TOEFL iBT reading sets were unfamiliar and irrelevant to the students' interests and background content knowledge i.e., specialization.

Participant T. 1 (a female student with a high proficiency level): Most of the topics of the reading sets are scientific, the thing which is suitable for scientific-section students rather than us, literary section students. Of course, scientific-section students will outperform us in the test.

Participant T. 3 (a female student with an intermediate proficiency level): In fact, I feel very anxious when I see the TOEFL iBT reading sets. The topics the test covers are not related to my field (i.e., education and literature). Even after finishing the training period, I did not like such issues at all.

Participant T. 4 (a male student with an intermediate proficiency level): luck plays a significant role in the TOEFL reading $i B T$. The topics of the reading sets may be relevant to some students' specializations and irrelevant to other students' fields.

Another problem reported by three students was related to vocabulary included in the TOEFL iBT reading sets. According to them, such words are difficult and irrelevant to their background knowledge i.e., specialization.

Participant T. 4 (a male student with an intermediate proficiency level) Sometimes, I find it very difficult to guess the meanings of unknown words in the routes. If the passages are related to our specialization, I can imagine the implications of obscure words. Neither the topics nor the words are related to our knowledge. How then can I guess the meaning of unknown words?

It is apparent that all students interviewed in this study had the same views on the topics and vocabulary of the reading sections of the TOEFL iBT test and the revised TOEFL paper-delivered 
test. From their perspectives, such topics and vocabulary are unfamiliar, complicated, and irrelevant to their background knowledge i.e., fields of study.

\section{Results of the Third Semi-structured Interview (an individual interview)}

To identify Al-Aqsa University EFL students' problems with the TOEFL iBT reading test as perceived by their instructors, the researcher conducted three individual interviews with three instructors who taught English reading at Al-Aqsa University. The interviews analysis revealed that the reading sections of the TOEFL iBT tests were the most problematic due to the topics of the reading sets.

Instructor 1: The problem is that the topics are super academic, and the students are not familiar with such issues.

Instructor 2: I think that the students have difficulties with most topics because they are difficult to understand and not covered in their university courses. Most English department students do not have any background knowledge about the information included in the passages.

Additionally, two interviewees revealed that one main factor contributing to the students' problems with the TOEFL iBT reading test was the students' lack of linguistic proficiency.

Instructor 2: Some students cannot answer the questions of the TOEFL reading tests because they do not have adequate linguistic abilities, such as grammatical and lexical competencies.

Instructor 3: Some students need to develop their linguistic abilities to be able to comprehend passages.

Instructor 2: The primary reason for the student's poor reading comprehension is a lack of linguistic knowledge. Indeed, many students do not have the required linguistic competence needed to practice reading comprehension and other language skills, such as listening, speaking, and writing.

Moreover, one of the three interviewees reported that some students complained about the length of the passages because they lacked exposure to such types of standardized tests. Instructor 3: I think that some students have problems with the length of the TOEFL iBT sets, perhaps because they used to get exposed to short passages rather than lengthy passages.

Furthermore, the interviews showed that the students' slow reading speed was another problem the students encountered when taking standardized tests, including the TOEFL iBT reading tests.

Instructor 2: Many students complained that the time of the test was not adequate. They need to develop their reading speed and train themselves on time limits when reading a passage.

To sum up, the interviews with the three instructors revealed the students' problems with the TOEFL iBT reading tests. Examples of such issues were the irrelevance of the TOEFL iBT reading sets to students' content background knowledge, students' lack of exposure to lengthy passages, students' slow reading speed, and students' lack of linguistic proficiency. 


\section{Discussion of the Research Results}

One of the study results indicated that all participants (i.e., the students with background experiences in the TOEFL preparation courses (2019-2021), the students who did not attend any TOEFL preparation courses, and the instructors) complained about the topics of the TOEFL iBT reading test and the revised TOEFL paper-delivered reading test. The topics are unfamiliar, complicated, and irrelevant to the students' interests and fields of study. Additionally, some students reported that luck might play a significant role in passing the TOEFL iBT reading tests. A topic of a reading set might be relevant to some students' content background knowledge and irrelevant to others' knowledge, depending on a student's specialization. The students' unfamiliarity with the topics of the TOEFL reading sets might prevent them from activating their content background knowledge i.e., content schemata. In this context, Carrell and Eisterhold (2012) view that the reader's failure to activate content schemata (the background knowledge of the content area of a text) results in many degrees of non-comprehension. Halfyard (1997) also emphasizes the significant role of background experiences in facilitating the process of reading. Based on that, the researcher advises E.T.S experts to select reading sets relevant to students' different content background knowledge i.e., specializations. In other words, the experts should prepare sets with various topics meeting all students' fields (i.e., preparing sets with scientific topics for scientific-section students and literary subjects for literary-section students, etc.). Consequently, the tests can activate the students' background content knowledge, and luck will not play a role in passing the TOEFL iBT reading tests.

A second result drawn in the present study was the students' inability to practice higher-order thinking skills. The interviews revealed that most of the students who did not attend any TOEFL reading iBT preparation courses were not able to use a certain number of reading sub-skills (i.e., predicting, summarizing, and finding information implied in the passages). In this respect, Hammad (2014) indicated that Gaza public preparatory students did not practice reading sub-skills required for arriving at a global understanding of a text, and they focused on explicit information in the texts. Moreover, Samad, Jannah, and Fitriani (2017) also found that the most challenging skills Syiah Kuala University students encountered when administering TOEFL reading comprehension test were deducing implied details, using context for guessing meanings of difficult words, finding main ideas, and determining meanings from word parts. According to Grellet (1981), reading includes understanding explicit and implicit information stated in a written text and going outside the text. A teacher should prepare a variety of exercises through which many skills are to be covered. Therefore, for EFL university students to reach complete comprehension of texts, both teachers and students at Al-Aqsa University should focus on reading sub-skills (i.e., higher-order thinking skills) including drawing inferences, summarizing, predicting, and making suggestions) in reading classes.

A third problem was students' slow reading speed. The three instructors in this study reported that most students were slow readers. Related to learners' reading speed, Chang and Millett (2013) view that timed reading activities can increase EFL students' reading speed and reading comprehension. Additionally, Macalister (010) provides that reading rate is one dimension of reading fluency. Macalister also states that a learner can develop reading speed through three approaches, including easy extensive reading (reading accessible texts for pleasure), repeated reading (reading the exact text repeatedly either silently or aloud) and speed reading (reading many readers of a fixed length written with a restricted lexicon followed by several multiple- 
choice questions). Nation (2009) also refers that speed reading is essential for developing reading fluency, where learners focus on increasing their reading speed with a good level of comprehension. In speed reading courses, the materials should be within the students' proficiency level. Thus, it is advisable for the Palestinian EFL teachers to time all reading activities since timing in silent reading could force learners to read faster. The study also advises the teachers to employ practical approaches (i.e., extensive reading, repeated reading, and speed reading) to develop the student's reading rate.

The fourth problem was that the student's lack of exposure to lengthy passages. The interviews with the three instructors showed that some students who had previous experiences with the TOEFL iBT reading preparation courses were concerned about the length of the TOEFL iBT reading passages. In this respect, Jalilehvand (2012) affirmed that text length had no statistically significant effect on the EFL students' performance in the reading comprehension tests. The primary reason for the student's concerns about the size of the passages might be the lack of exposure to longer texts in reading classes. Consequently, the study strongly advises Gaza EFL instructors to train the students to practice reading longer texts in English reading classes.

A final problem was the students' lack of linguistic proficiency. According to the three instructors interviewed in the present study, lack of linguistic ability (lexis and grammar) contributed to poor reading comprehension and low scores in all reading tests, including the TOEFL iBT reading tests. Congruent with this result, some studies (e.g., Akmal, Risdaneva, Habiburrahim, \& Sari, 2020; Fajri, 2019) indicated that lack of vocabulary was one of the Indonesian EFL students' problems with the TOEFL tests. Tsai (2018) provides that there is a correlation between linguistic knowledge and reading comprehension. According to Tsai, a learner can facilitate reading comprehension through linguistic knowledge at different levels, including the lower-level processing (i.e., orthographic knowledge, vocabulary knowledge, and word recognition process) and higher-level processing (i.e., syntactic expertise and knowledge of text structure). Consequently, it is recommendable for English department students at Al-Aqsa University to develop their linguistic competence since it is crucial to enhance their reading comprehension levels.

\section{Recommendations}

Based on the above, the study offers the following recommendations:

- The study advises E.T.S experts to select reading sets relevant to students' different content background knowledge i.e., fields of study. In other words, the experts should prepare sets with various topics meeting all students' specializations (i.e., preparing sets with scientific topics for scientific-section students and literary subjects for literarysection students, etc.). Consequently, the students can activate their background content knowledge, and luck will not play a role in passing the TOEFL iBT reading tests.

- It is recommendable for both teachers and students at Al-Aqsa University to focus on EFL reading sub-skills (i.e., higher-order thinking skills), including drawing inferences, summarizing, predicting, and making suggestions) in reading classes.

- It is advisable for the Gaza EFL teachers to time all reading activities since timing in silent reading could force learners to read faster. The teachers should also employ practical 
approaches (i.e., extensive reading, repeated reading, and speed reading) to develop the student's reading rate.

- The study advises Gaza EFL instructors to train the students to practice reading longer texts in English reading classes.

- It is advisable for English department students at Al-Aqsa University to develop their linguistic competence since it is crucial to enhance their reading comprehension levels.

\section{Conclusion}

The study indicated that the participants' performance level in the revised TOEFL paperdelivered reading test was flawed. It reported the students' problems with the revised TOEFL paper-delivered reading test as perceived by the students. Such issues included the irrelevance of the topics of the TOEFL paper-delivered reading sets to the student's content background knowledge, the irrelevance of the vocabulary included in the TOEFL paper-delivered reading tests to the student's background knowledge, lack of opportunities for training students on practicing higher-order thinking skills (i.e., predicting, summarizing, and finding information implied in the passages), and student's inability to work under time pressure. Furthermore, the study revealed that the students with background experiences in the TOEFL iBT reading tests had problems with the topics and vocabulary of the reading sections of the TOEFL iBT test. From their perspectives, such issues and language are unfamiliar, complicated, and irrelevant to their background knowledge i.e., the field of study. Additionally, results showed the students' problems with the TOEFL iBT reading sets as perceived by their instructors i.e., students' lack of exposure to lengthy passages, the irrelevance of the topics of the TOEFL iBT reading scenes to students' content background knowledge, students' slow reading speed, and students' lack of linguistic ability.

\section{About the author}

Enas Abdullah Hammad has been teaching TEFL courses at Al-Aqsa University since 2007. From 1998-2007, she worked as a teacher of English at Gaza private, governmental, and United Nations Relief and Work Agency schools. She is the winner of the 2010 Sheikh Nahayan Doctoral Dissertation Fellowship. Her research interests include EFL listening, speaking, reading, and writing. ORCid ID: https://orcid.org/0000-0001-5003-7168.

\section{References}

Akmal, S., Risdaneva, H., \& sari, M. (2020). The English teachers' challenges in TOEFL preparation for senior high school students. JEFL, 10(1),24-44.

Retrievedfromhttps://pdfs.semanticscholar.org/6912/466d2173fd48496c90838b18a511b6dcc710. pdf?_ga=2.155825523.95329297.1629424920-61988025.1624199347

Al-Aqsa University (2020). Al-Aqsa University. Retrieved from

https://www.alaqsa.edu.ps/en/page/2650/Alaqsa-University-Gaza-About-AQU

Ariola, M.M. (2006). Principles and methods of research. Philippine: Book Store.

Asrida, R., \& Fitrawati (2019). The difficulties of English department students at Universitas Negeri Padang in answering reading section of TOEFL. Journal of English Language Teaching, 8(4), 496-503.

Assiri, M.S. (2011). Test-taking strategy use on the reading section of the TOEFL iBT: A study of Arab ESL learners. (Unpublished Doctoral Dissertation). Retrieved from https://shareok.org/bitstream/handle/11244/7051/English\%20Department_02.pdf?sequence=1

Carrell, P., \& Eisterhold, C. (2012). Schemata theory and ESL reading pedagogy. In P. Carrell, J. Devine, \& D. Eskey. (Eds). International approaches to second language reading (pp.80-99). Cambridge: Cambridge Press. 
Castello, E. (2008). Li85, Linguistic insights: Studies in Language and communication. Text complexity and reading comprehension tests. Berlin: Peter Lang.

Chang, A., \& Millett, S. (2013). Improving reading rates of comprehension through timed repeated reading. Reading in A foreign Language, 25(2)126-148.

Cho, Y., \& Bridgeman, B. (2012). Relationship of TOEFL iBT ® scores to academic performance: Some evidence from American universities. Language Testing, 29(3),421-442. Doi: $10.1177 / 0265532211430368$

ETS (2021). About the revised TOEFL paper-delivered Test. Retrieved from https://www.ets.org/toefl/rpdt/aboutt/

ETS (2019). TOEFL iBT prep plus 2020-2021: For the revised TOEFL iBT. New York: Kaplan.

ETS (2009). The official guide to the TOEFL iBT. New York: McGraw-Hill.

ETS (2008). TOEFL iBT tips: How to prepare for the TOEFL iBT. Retrieved from https://www.ets.org/toefl

Fajri, D.R. (2019). An analysis of student strategy in completing the TOEFL reading comprehension test. JELTL, 2(2), 84-91.

Galikyan, I., Madyarov, I., \& Gasparyan, R. (2019). Student test takers' and teachers' perceptions of the TOEFL junior ${ }^{\circledR}$ standard test. Educational Testing Service, 1, 1-15 Retrieved fromhttps://onlinelibrary.wiley.com/doi/full/10.1002/ets2.12264

Girsang, A., Marbun, F., Turnip, Y., \& Saragih, E. (2019). An analysis of reading comprehension difficulties in TOEFL test by high school students. LEEA, 3(1), 132-137.

Grellet, F. (1981). Developing reading skills. Cambridge: Cambridge University Press.

Halfyard, G. (1997). Reading experiences and strategies of reluctant grade 6 and 7 students. (Unpublished Doctoral dissertation). University of Victoria, USA.

Hammad, E. (2014). Palestinian teachers' use of questioning in two different instructional settings of EFL reading. In K. Bailey \& R. Damerow (Eds). Teaching and learning English in the Arab-speaking world (pp.115-132). New York: TIRF \& Routledge.

Jalilehvand, M. (2012). The effects of text length and picture on reading comprehension of Iranian EFL students. Asian Social Science, 8(3),329-337.

Lodico, M., Spaulding, D., \& Voegtle, K. (2006). Methods in educational research: From theory to practice. San Francisco: John \& Sons. Inc.

Macalister, J. (2010). Speed reading courses and their effect on reading authentic texts: A preliminary investigation. Reading in A foreign Language, 22(1)104-116.

Menter, I. et al. (2011). A guide to practitioner research in education. London: SAGE.

Nation I. (2009). Teaching ESL/EFL reading and writing. New York: Routledge.

O'Dwyer, J., Kantarcioglu, E., \& Thomas, C. (2018). An investigation of the predictive validity of the TOEFL iBT test at an English-Medium university in Turkey. U.S.A.: Wiley Online Library

Putlack, M., Poirier, S., \& Jacobs, A. (2020). Decoding the TOEFL ® iBT: Actual test, reading 2. Korea: Darakwon

Putlack, M., Poirier, S., and Jacobs, A. (2015). Decoding the TOEFL ® iBT: Actual test, reading 2. Korea: Darakwon

Samad, I.A., Jannah, M., \& Fitriani, S. (2017). EFL students' strategies dealing with common difficulties in TOEFL reading comprehension section. International Journal of Language Education, 1(1), 29-36.

Sari, M. (2019). English language teachers' self-reported perceptions on TOEFL preparation program in senior high school. (Unpublished Doctoral Dissertation), Islam Negeri Ar-Raniry Banda Aceh, Indonesia. Retrieved from https://repository.arraniry.ac.id/id/eprint/10966/1/Maulina\%20Sari\%2C\%20150203096\%2C\%20 FTK\%2C\%20PBI\%2C\%20081322942334.pdf

Soureshjani, K., Riahipour, P., \& Safikhani, A. (2012). An investigation into the Iranian EFL language learners' attitudes on TOEFL iBT. Language Testing in Asia, 2(3),18-32. 
Stirling, B. (2021). Practice tests for the TOEFL iBT. West Hollywood: Nova Press

Tsai, Y. (2018). Fostering EFL learners' reading comprehension through a web-based calmative sentence analysis (CSA) system. In R. Sharma (Ed). Innovative applications of online pedagogy and course design (pp.202-222). U.S.A.: IGI Global.

$\mathrm{Vu}, \mathrm{L} .$, \& Vu, P. (2013). Is the TOEFL score a reliable indicator of international graduate students' academic achievement in American higher education? International Journal on Studies in English Language and Literature, 1(1), 11-19.

Zalha, F., Alfiatunnur, A., \& Kamil, C. (2020). Strategies in dealing with the reading section of 'TOEFL Prediction': A case of Aceh EFL learners. Indonesian Journal of English education, 7(2), Available at file:///C:/Users/Dell/Documents/II17.htm

\section{Declaration of Conflicting Interests}

The author declared no potential conflicts of interest with respect to the publication of the research.

\section{Funding}

The author received no financial support for the research and publication of this research

\section{Appendixes}

Appendix (A): The Questions of the First Semi-structured Interview

1. What problems did you encounter when taking the Revised TOEFL paper-delivered Reading Test?

2. Were the topics or contents of the sets challenging? If yes, why?

3. Was the vocabulary included in the sets challenging? If yes, why?

4. Were the questions associated with the sets difficult? If yes, why?

5. Did you have problems with the time allocated for the Revised TOEFL paper-delivered Test? If yes, why?

\section{Appendix (B): The Questions of the Second Semi-structured Interview}

1. What problems did you encounter when taking the TOEFLiBT Reading Test?

2. Were the topics or contents of the sets challanging? If yes, why?

3. Was the vocabulary included in the sets complicated? If yes, why?

4. Were the questions associated with the passages difficult? Why/Why not?

5. Was the time allocated for the TOEFL iBT Reading Test adequate? Why/Why not?

6. In case of having problems related to the previous aspects, did you overcome such problems with the help of TOEFL preparation courses? If yes, what problems did you overcome with the help of the TOEFL preparation courses, how?

\section{Appendix (C): The Questions of the Third Semi-structured Interview}

1. Do English department students at Al-Aqsa University have problems with the topics and contents of the TOEFL iBT Reading Test? If yes, why? Is the student's content knowledge limited? Are the topics or contents irrelevant to the students' university courses?

2. Do English department students at Al-Aqsa University have problems with the vocabulary included in the TOEFL iBT Reading Test? If yes, why? Is the students' linguistic knowledge limited? Is the language complex?

3. Do English department students at Al-Aqsa University have problems with the time devoted to the TOEFLiBT Reading Test? Why/Why not

4. Do English department students at Al-Aqsa University have problems with the questions associated with the Revised TOEFL paper-delivered Test and the TOEFL iBT Reading Test? Why/Why not?

5. What other problems do English department students encounter when taking the TOEFL iBT Reading Test?

Appendix (D): The Revised TOEFL paper-delivered Test

ETS (2019). TOEFL iBT prep plus 2020-2021: For the revised TOEFL iBT. New York: Kaplan 